\title{
Dampak Perubahan Curah Hujan Terhadap Tingkat Kerentanan Erosi Tanah di Sub DAS Merawu, Jawa Tengah
}

\author{
The Impact of Rainfall Changes on The Level of Vulnerability of Soil \\ Erosion in The Merawu Sub-Watershed, Banjar Negara District, \\ Central Java
}

\author{
Donnie Koes Nugraha ${ }^{\circledR}$, Bayu Dwi Apri Nugroho ${ }^{1}$ dan Chandra Setyawan ${ }^{1}$ \\ ${ }^{1}$ Departemen Teknik Pertanian dan Biosistem, Fakultas Teknologi Pertanian, Universitas Gadjah Mada

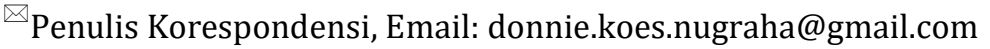 \\ DOI:http://dx.doi.org/10.23960/jtep-l.v10i3.356-366
}

Naskah ini diterima pada 17 Mei 2021; revisi pada 30 Juli 2021; disetujui untuk dipublikasikan pada 10 Agustus 2021

\begin{abstract}
Merawu Sub-Watershed is vulnerable due to soil erosion caused by change of the rainfall. This research was held to estimate rainfall and change in soil erosion vulnerability from 2020 to 2050 in Merawu Sub-Watershed, Banjanegara District with RCP 2.6, 4.5 and 8.5. The RCP is an overview of the concentration trends for greenhouse gases, aerosols and land use change created by the climate modeling community. Rainfall prediction was generated from SDSM Software and combined with USLE to predict soil erosion in ArcGIS 10.4. Changes in rainfall intensity are an important factor in changes of soil erosion rates because the kinetic energy of falling rainwater can cause soil erosion. The results showed rainfall in Banjarnegara Station at 2020-2050 with RCP 2.6,4.5 and 8.5 were increasing by $+0,26 \% ;+0,60 \% ;+0,52 \%$, while in Kalisapi Station were decreasing by $-1,54 \% ;-1,65 \%$ dan $-2,20 \%$. The change of soil erosion vulnerability prediction showed that soil erosion in Sub-DAS Merawu at 2020-2050 with RCP 2.6,4.5 and 8.5 in very light category were -0,02\%; -0,02\%; -0,03\%, light category were -0,17\%; -0,17\%; -0,17\%, moderate category $-0,05 \% ;-0,05 \% ;-0,04 \%$, heavy category $0,26 \% ;-0,35 \% ;-0,37 \%$, and very heavy category were $+1,46 \% ;+1,88 \% ;+1,95 \%$. While the average soil erosion prediction at $R C P 2.6,4.5$ and 8.5 were $+0,86,+1,19 \%$ and $+1,03 \%$, respectively.
\end{abstract}

Keywords: Merawu Sub- Watershed, rainfall prediction, SDSM Software, soil erosion prediction

\begin{abstract}
ABSTRAK
Perubahan curah hujan yang terjadi karena perubahan iklim menjadi tantangan daerah yang rentan erosi tanah, dimana salah satunya adalah Sub DAS Merawu. Penelitian ini bertujuan memrediksi curah hujan dan perubahan tingkat kerentanan erosi tanah tahun 2020-2050 di Sub DAS Merawu, Kabupaten Banjarnegara dengan RCP 2.6, RCP 4.5 dan RCP 8.5. RCP adalah gambaran trend konsentrasi untuk gas rumah kaca, aerosol dan perubahan tata guna lahan yang dibuat oleh komunitas pemodelan iklim. Prediksi curah hujan dilakukan dengan software SDSM, selanjutnya dilakukan analisa spasial dengan ArcGIS 10.4 untuk mengetahui nilai erosi tanahnya dengan metode USLE. Perubahan intensitas hujan menjadi faktor penting dalam perubahan tingkat erosi tanah karena tenaga kinetik dari air hujan yang jatuh dapat menyebabkan erosi tanah. Hasil prediksi curah hujan tahun 2020-2050 pada Stasiun Banjarnegara untuk RCP 2.6, 4.5 dan 8.5 bertambah 0,26\%; 0,60\%; 0,52\%, pada Stasiun Kalisapi untuk RCP 2.6, 4.5 dan 8.5 berkurang -1,54\%; $-1,65 \%$ dan -2,20. Hasil prediksi perubahan tingkat kerentanan erosi pada Sub-DAS Merawu untuk RCP 2.6; RCP 4.5 dan RCP 8.5 dengan kategori erosi sangat ringan -0,02\%;-0,02\%;-0,03\%, kategori ringan -0,17\%;$0,17 \% ;-0,17 \%$, kategori sedang $-0,05 \% ;-0,05 \% ;-0,04 \%$, kategori berat $-0,26 \% ;-0,35 \% ;-0,37 \%$, kategori sangat berat naik 1,46\%; 1,88\%; 1,95\%. Sedangkan nilai prediksi rata-rata erosi tanah pada RCP 2.6 naik 0,86\%, RCP 4.5 naik 1,19\% dan RCP 8.5 naik 1,03\%.
\end{abstract}

Kata Kunci: prediksi curah hujan, prediksi erosi tanah, software SDSM, Sub DAS Merawu 


\section{PENDAHULUAN}

Perubahan iklim menjadi tantangan di bidang pertanian khusunya yang terkait dengan erosi tanah. Menurut Nearing (2001), salah satu dampak perubahan iklim terkait erosi tanah terjadi karena perubahan kekuatan erosi yang disebabkan perubahan jumlah curah hujan dan intensitas hujan. Menurut Yang et al. (2003), rata-rata erosi tanah diproyeksikan naik hingga 9\% pada tahun 2090 dikarenakan perubahan iklim. Perubahan iklim diperkirakan menyebabkan perubahan atribut curah hujan karena peningkatan kelembaban spesifik atmosfer pada iklim di masa depan yang lebih hangat (Polade et al., 2017). Selain perubahan iklim, peningkatan populasi manusia yang tidak diimbangi dengan peningkatan usaha pelestarian sumber daya alam juga menjadi masalah di masa depan.

Pulau Jawa tercatat memiliki 16 Daerah Aliran Sungai (DAS) dengan kondisi sangat kritis (Mawardi, 2010). Salah satu diantaranya yang mengalami kondisi kritis adalah DAS Serayu. Di dalam DAS Serayu terdapat Sub DAS Merawu yang mengalami erosi lahan yang cukup tinggi dan berubah-ubah. Perubahan erosi tersebut dipengaruhi oleh banyak faktor seperti faktor penggunaan lahan, pemanfaatan lahan, karakteristik tanah serta faktor curah hujan (Marhendi, 2011).

Dalam praktiknya, pemanfaatan lahan di Sub DAS Merawu dianggap belum memperhatikan kaidah konservasi sehingga potensi dan kualitas lahan juga belum optimal. Keterbatasan dalam pengelolaan lahan dapat berakibat pada penurunan potensi lahan dan penurunan potensi tata air yang secara mudah terlihat pada banjir dan sedimentasi pada daerah hilir. Hal ini tentu merupakan hasil dari pengolahan lahan yang kurang memperhatikan sifat lahan tersebut sehingga terjadi kerusakan DAS yang menyebabkan bencana alam seperti tanah longsor dan banjir.

Menurut Nugroho (2020), ada 4 indikator perubahan iklim yang dapat menjelaskan adanya perubahan iklim yakni perubahan suhu daratan, peningkatan curah hujan ekstrim, mundurnya musim dan perubahan jumlah volume hujan. Fenomena perubahan iklim ini memiliki berbagai dampak yang dapat merugikan sektor pertanian. Erosi tanah menjadi salah satu yang terpengaruh fenomena perubahan iklim dikarenakan erosi tanah terdampak peningkatan curah hujan dan perubahan volume hujan.

Melihat adanya fenomena perubahan iklim dan masalah kerentanan erosi di DAS Merawu, maka penelitian ini bertujuan untuk mengetahui prediksi curah hujan dan mengetahui prediksi perubahan tingkat kerentanan erosi tahun 2020-2050 di Sub DAS Merawu, Kabupaten Banjarnegara pada RCP 2.6, 4.5 dan 8.5.

\section{BAHAN DAN METODE}

\subsection{Alat dan Bahan}

Alat yang digunakan dalam penelitian ini meliputi software ArcGIS 10.4 dan SDSM. ArcGIS 10.4 digunakan untuk mengolah data spasial dan memodelkan daerah penelitian. Software SDSM digunakan untuk melakukan proyeksi curah hujan tahun 2020-2050 yakni periode jangka pendek dan jangka menengah menurut Bappenas (2018). Bahan dalam penelitian ini meliputi data curah hujan di Kab. Banjarnegara yang diwakili dari 2 stasiun, yakni Banjarnegara dan Kalisapi tahun 19992019 dari Balai Besar Wilayah Sungai SerayuOpak (BBWS S-0), Statistical Downscaling Scenario (SDSM) untuk National Center For Enviromental Prediction (NCEP) dan RCP (Representative Concentration Pathway) dari Canadian Earth System Model (CanESM), peta Digital Elevation Model (DEM), peta jenis tanah dan peta penggunaan lahan tahun 2019, peta administrasi, serta peta rupa bumi Indonesia Lembar 1408-412 skala 1:25.000. Tahapan penelitian dijelaskan pada Gambar 1.

\subsection{Analisa Data}

\subsubsection{Perhitungan Prediksi Erosi Tanah}

Metode pendekatan rumus umum besarnya tanah hilang dengan menggunakan rumus umum kehilangan tanah (Universal Soil Los Equation). Menurut Wischmeier dan Smith (1978), USLE menghitung laju erosi tanah (A) menggunakan Persamaan 1 : 


$$
\mathrm{A}=\text { R. K. LS. C. P }
$$

dimana, A adalah tanah yang hilang dalam ton.ha-1.tahun ${ }^{-1}$, $\mathrm{R}$ adalah erosivitas hujan (MJ.mm.ha-1.tahun ${ }^{-1}$ ), $\mathrm{K}$ adalah indeks erodibilitas tanah (ton.ha.MJ-1. $\mathrm{mm}^{-1}$.tahun ${ }^{-1}$ ), LS adalah indeks kemiringan dan panjang lereng, C adalah indeks vegetasi penutup (penggunaan lahan), dan $\mathrm{P}$ adalah indeks konservasi tanah.

\subsubsection{Uji Validasi RMSE}

RMSE (Root Mean Square Error) menghitung seberapa berbedanya seperangkat nilai. Nilai RMSE yang rendah menunjukkan bahwa variasi nilai yang dihasilkan oleh suatu model prakiraan mendekati variasi nilai obeservasi. Semakin mendekati 0 nilai RMSE, semakin baik nilai prediksi. RMSE dihitung dari Persamaan 2 (Chai dan Draxler, 2014):

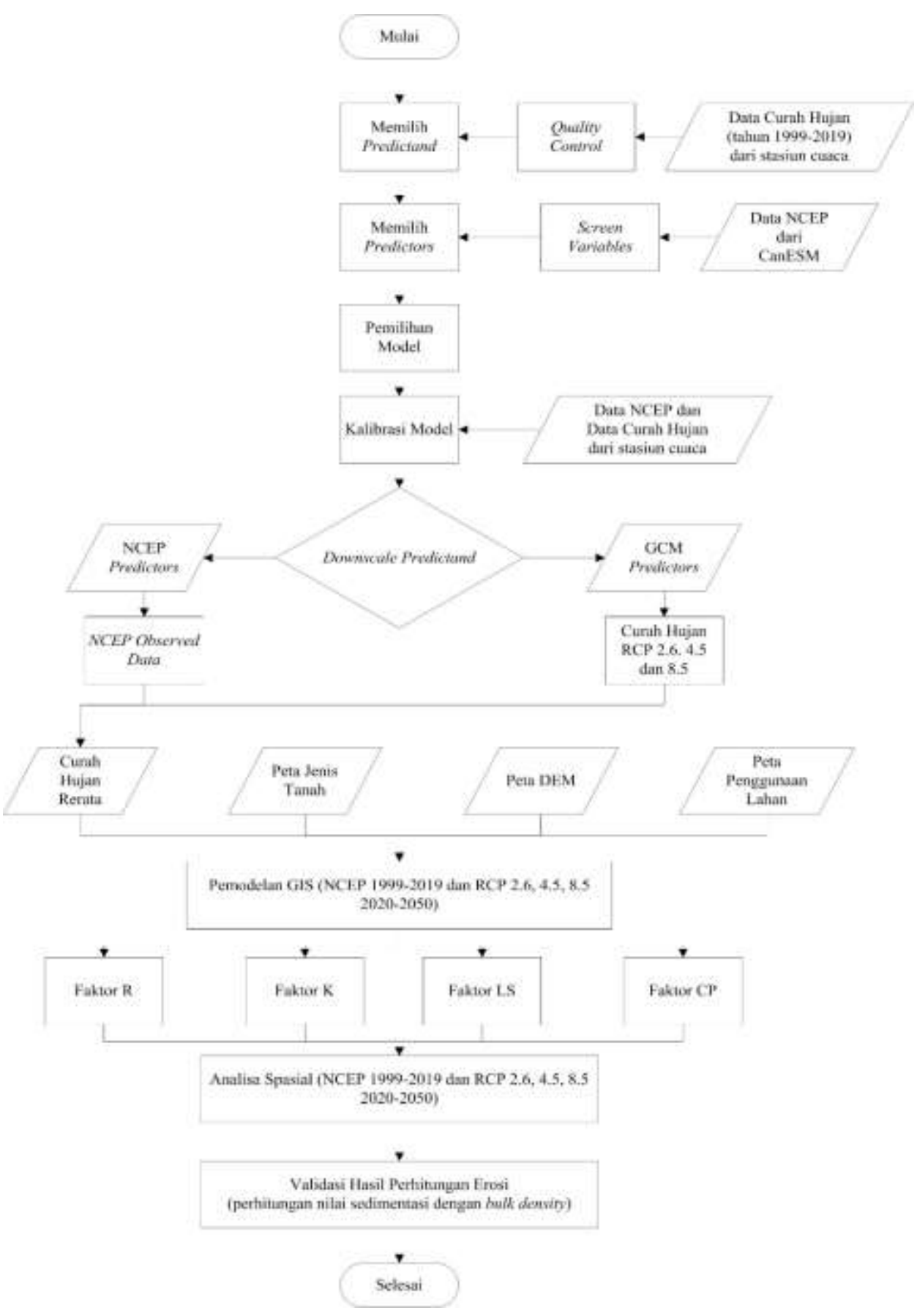

Gambar 1. Diagram Alir Penelitian 


$$
R M S E=\sqrt{\frac{\sum_{\mathrm{i}=1}^{\mathrm{n}}\left(y_{i}-\hat{y}_{i}\right)^{2}}{\mathrm{n}}}
$$

dimana $y$ adalah nilai hasil observasi, $\hat{y}$ adalah nilai hasil prediksi, $i$ adalah urutan data pada database, dan $n$ adalah jumlah data.

\subsubsection{Uji Validasi NMSE}

Uji NMSE (Normalized Mean Square Error) biasa digunakan untuk mengurangi bias pada hasil prediksi, dimana hasil prediksi dapat memiliki data yang overpredict atau bahkan underpredict sehingga perlu ada normalisasi data prediksi. Semakin mendekati 0 nilai NMSE, maka semakin baik nilai yang diprediksi dan diamati. NMSE dihitung dari Persamaan 3 (Poli dan Cirillo, 1993):

$$
N M S E=\frac{R M S E}{\bar{x}}
$$

dimana $\bar{x}$ nilai rata-rata data observasi.

\subsubsection{Uji NSE}

Uji NSE (NASH-Sutcliffe Efficiency) biasa digunakan untuk melihat bagaimana hasil prediksi sesuai dengan hasil observasi yang digambarkan pada grafik garis 1:1. Semakin mendekati 1 nilai NSE, maka semakin baik nilai yang diprediksi. Nilai NSE dihitung melalui Persamaan 4 (Moriasi et al., 2007):

$$
N S E=1-\frac{\sum_{t=1}^{T}\left(Q_{o}^{t}-Q_{p}^{t}\right)^{2}}{\sum_{t=1}^{T}\left(Q_{o}^{t}-\bar{Q}_{o}\right)^{2}}
$$

dimana $Q_{o}^{t}$ adalah nilai hasil observasi, $Q_{p}^{t}$ adalah nilai hasil prediksi, $\bar{Q}_{o}$ adalah nilai rata-rata hasil observasi, $t$ adalah urutan data pada database, subskrip $o$ adalah observasi, dan $p$ adalah prediksi.

\subsubsection{Uji Correlation Coefficient}

Uji Correlation Coefficient (CC) digunakan untuk mengukur seberapa kuat hubungan antara dua variabel. Semakin mendekati 1 atau -1 nilai CC, maka semakin kuat hubungan antara 2 variabel. Jika nilai $C C$ mendekati 0 , maka dapat dikatakan bahwa hubungan antara 2 variabel cenderung lemah. Nilai $C C$ dihitung dari Persamaan 5 (Asuero et al., 2006):

$$
C C=\frac{n\left(\sum x y\right)-\left(\sum x\right)(y)}{\sqrt{\left[\sum x^{2}-\left(\sum x\right)^{2}\right]\left[n \sum y^{2}-\left(\sum y\right)^{2}\right]}}
$$

dimana $x$ adalah nilai hasil observasi, $y$ adalah nilai hasil prediksi, dan $n$ adalah jumlah data.

\subsubsection{Perhitungan Prediksi Sedimentasi}

Metode pendekatan rumus umum besarnya sedimentasi dengan menggunakan rumus Sediment Deposits (SD). Menurut World Meteorological Organization (1981), Sediment Deposits dihitung menggunakan Persamaan 6:

$$
S D=\frac{\text { Laju Erosi } x \text { Luas area }}{\text { Bulk Density }}
$$

dimana, $S D$ adalah jumlah sedimentasi $\left(\mathrm{m}^{3}\right)$, laju erosi tanah yang hilang (ton/ha), luas area adalah luas daerah cakupan (ha), dan Bulk Density adalah kerapatan volumetrik (ton $/ \mathrm{m}^{3}$ ).

\section{HASIL DAN PEMBAHASAN}

\subsection{Pemilihan Variabel Prediktor SDSM}

Terdapat 26 prediktor dalam NCEP yang digunakan dalam penelitian ini dengan software SDSM. Dari 26 prediktor tersebtut, diketahui bahwa 2 variabel prediktor yakni aliran zonal pada lapisan $1000 \mathrm{hPa}(1000 \mathrm{hPa}$ Zonal velocity) dan suhu udara pada ketinggian $2 \mathrm{~m}$ (Screen $2 \mathrm{~m}$ air temperature) memiliki signifikansi yang tinggi untuk curah hujan di daerah Banjarnegara. Kedua variabel prediktor berkorelasi parsial positif dengan partial $r>0$ dan memiliki nilai signifikansi 95\% $(\mathrm{p}<0,05)$.

Variabel prediktor $1000 \mathrm{hPa}$ Zonal velocity adalah aliran angin pada sumbu $x$ bumi atau sejajar dengan lingkar lintang pada tekanan $1000 \mathrm{hPa}$. Menurut Aiqiu et al. (2017), lapisan isobarik $1000 \mathrm{hPa}, 925 \mathrm{hPa}, 850 \mathrm{hPa}, 700 \mathrm{hPa}$ dan $500 \mathrm{hPa}$ memiliki potensi kuat dalam proses pembentukan awan dan pertumbuhan awan. Pertumbuhan awan ini sebagai dampak kelembapan udara tinggi yang dihasilkan daerah tersebut. Kelembapan udara yang tinggi ini nantinya menghasilkan hujan pada daerah tersebut.

Selain aliran udara pada $1000 \mathrm{hPa}$, suhu udara pada ketinggian $2 \mathrm{~m}$ menjadi salah satu variabel yang signifikan. Screen $(2 \mathrm{~m})$ air temperature adalah suhu udara pada ketinggian $0-2 \mathrm{~m}$ dari permukaan bumi yang 
diturunkan dari interpolasi prediksi temperatur udara pada $10 \mathrm{~m}$ dan prediksi suhu permukaan bumi. Hal ini menandakan bahwa pengaruh tutupan lahan serta aktivitas manusia yang berkaitan dengan penambahan suhu permukaan bumi juga mempengaruhi kejadian hujan di daerah tersebut.

Selanjutnya, prediktor ini digunakan sebagai indeks dalam menentukan nilai prediksi curah hujan. Dalam mengevaluasi variabel prediktor, hasil sangat bergantung pada keakuratan data curah hujan dan lama periode pencatatan curah hujan di lokasi yang kita ajukan sebagai bahan penelitian. Sehingga, semakin baik data dan semakin panjang data pencatatan curah hujan, maka semakin akurat evaluasi variabel prediktor dan prediksi curah hujannya akan semakin mendekati kondisi nyatanya.

\subsection{Validasi dan Kalibrasi Hasi Downscaling Model}

Setelah variabel prediktor dipilih, maka dilakukan pembuatan data prediksi curah hujan sesuai kebutuhan kita. Data tersebut lalu divalidasi dengan beberapa indeks kinerja sesuai dengan hasil data observasi kita. Pada prediksi cuaca dengan software SDSM, data divalidasi dengan Root Mean Square Error (RMSE), Normalized Mean Square Error (NMSE), Nash-Sutcliffe Coefficient (NASH) dan Correlation Coefficient (CC) (Duhan dan Pandey, 2015). Hasil validasi nilai prediksi curah hujan disajikan dalam Tabel 1.

Berdasarkan pengujian RMSE, NMSE, NASH dan CC, nilai RMSE dan NMSE pada stasiun Banjarnegara lebih tinggi dibandingkan nilai RMSE dan NMSE di stasiun Kalisapi. Sedangkan pada pengujian NASH dan CC, nilai pada stasiun Kalisapi lebih tinggi daripada stasiun Banjarnegara. Nilai ini berkorelasi dengan hasil prediksi dari kedua stasiun. Di sisi lain, hasil prediksi tersebut dipengaruhi oleh data observasi curah hujan dari kedua stasiun. Dapat diambil kesimpulan sementara pada pengujian validasi diatas bahwa data prediksi dari stasiun Kalisapi lebih baik daripada data prediksi di stasiun Banjarnegara.

\subsection{Hasil Prediksi Curah Hujan SDSM pada Tahun 2020-2054}

Setelah dipilih variabel prediktor yang berpengaruh pada data curah hujan historis, maka dapat dilakukan prediksi dengan variabel prediktor tersebut. Pada data historis, variabel prediktor yang berpengaruh adalah $1000 \mathrm{hPa}$ Zonal velocity dan Screen $(2 \mathrm{~m}$ ) air temperature. Dari kedua variabel prediktor dan data curah hujan historis didapatkan hasil prediksi curah hujan 5 tahunan pada 20202054 RCP 2.6, 4.5 dan 8.5 dengan software SDSM. Hasil prediksi tersebut dapat dilihat pada Tabel 2.

Jika dilihat dari Tabel 2, selisih curah hujan prediksi dibanding dengan curah hujan historis tahun 2015-2019, memiliki nilai yang curah hujan yang cenderung meningkat pada Stasiun Banjarnegara dan cenderung menurun pada Stasiun Kalisapi. Hasil prediksi curah hujan pada Stasiun Banjarnegara lebih tinggi dibandingkan pada Stasiun Kalisapi meskipun keduanya memiliki variabel prediktor yang sama yakni $1.000 \mathrm{hPa}$ Zonal velocity dan Screen (2 m) air temperature. Curah hujan pada Stasiun Banjarnegara lebih tinggi karena lokasi di sekitar stasiun itu didominasi oleh perkebunan dan sawah dimana vegetasinya

Tabel 1. Tabel Uji Validasi RMSE, NMSE, NASH, dan CC Tahun 2020-2054

\begin{tabular}{llccc}
\hline Pengujian & \multicolumn{1}{c}{ Stasiun } & RCP 2.6 & RCP 4.5 & RCP 8.5 \\
\hline RMSE & Banjarnegara & $0,816-1,581$ & $0,913-2,102$ & $1,041-2,466$ \\
& Kalisapi & $0,408-0,764$ & $0,500-1,041$ & $0,645-1,000$ \\
\hline \multirow{2}{*}{ NMSE } & Banjarnegara & $0,559-0,115$ & $0,066-0,153$ & $0,076-0,179$ \\
& Kalisapi & $0,038-0,071$ & $0,046-0,096$ & $0,060-0,092$ \\
\hline \multirow{2}{*}{ NASH } & Banjarnegara & $0,955-0,988$ & $0,921-0,985$ & $0,891-0,981$ \\
& Kalisapi & $0,983-0,995$ & $0,969-0,993$ & $0,972-0,988$ \\
\hline CC & Banjarnegara & $0,981-0,996$ & $0,969-0,994$ & $0,957-0,991$ \\
& Kalisapi & $0,992-0,998$ & $0,995-0,998$ & $0,986-0,995$ \\
\hline
\end{tabular}


Tabel 2. Tabel Hasil Prediksi Curah Hujan RCP 2.6, 4.5 dan 8.5

\begin{tabular}{cccc}
\hline \multirow{2}{*}{ Tahun } & Data Hujan & \multicolumn{2}{c}{ Staisun } \\
\cline { 3 - 4 } & Historikal & $\begin{array}{c}\text { Banjarnegara } \\
\text { (mm/tahun })\end{array}$ & $\begin{array}{c}\text { Kalisapi } \\
\text { (mm/tahun })\end{array}$ \\
\hline $2015-2019$ & RCP 2.6 & 6.059 & 4.745 \\
\hline $2020-2024$ & RCP 4.5 & 5.986 & 4.636 \\
& RCP 8.5 & 5.950 & 4.636 \\
& RCP 2.6 & 6.986 & 4.599 \\
\hline $2025-2029$ & RCP 4.5 & 6.169 & 4.745 \\
& RCP 8.5 & 6.165 & 4.672 \\
& RCP 2.6 & 6.132 & 4.709 \\
\hline $2030-2034$ & RCP 4.5 & 6.096 & 4.709 \\
& RCP 8.5 & 6.059 & 4.745 \\
& RCP 2.6 & 6.023 & 4.672 \\
\hline $2035-2039$ & RCP 4.5 & 6.023 & 4.599 \\
& RCP 8.5 & 6.059 & 4.599 \\
\hline $2040-2044$ & RCP 2.6 & 6.059 & 4.636 \\
& RCP 4.5 & 6.132 & 4.599 \\
& RCP 8.5 & 6.059 & 4.599 \\
\hline $2045-2049$ & RCP 2.6 & 6.096 & 4.672 \\
& RCP 4.5 & 6.132 & 4.709 \\
& RCP 8.5 & 6.169 & 4.636 \\
\hline $2050-2054$ & RCP 2.6 & 6.059 & 4.709 \\
& RCP 4.5 & 6.132 & 4.709 \\
& RCP 8.5 & 6.132 & 4.672 \\
\hline
\end{tabular}

lebih rapat jika dibandingkan dengan Stasiun Kalisapi yang lokasinya didominasi oleh tegalan dan sawah tadah hujan dengan vegetasi tidak terlalu rapat.

Selain itu faktor topografi juga berbeda cukup signifikan dimana lokasi Stasiun Banjarnegara berada pada ketinggian 291 mdpl, sedangkan Stasiun Kalisapi berada pada ketinggian 79 mdpl. Ketinggian tempat berpengaruh pada suhu permukaan dimana tempat yang lebih tinggi memiliki suhu yang cenderung lebih rendah dikarenakan kelembapan udara yang tinggi. Perbedaan vegetasi dan topografi membuat lokasi ini memiliki kelembapan udara dan suhu permukaan yang berbeda.

Prediksi perubahan curah hujan tahun 20202050 di Sub DAS Merawu yang disebabkan karena faktor $1.000 \mathrm{hPa}$ Zonal velocity dan Screen $(2 \mathrm{~m})$ air temperature pada Stasiun Banjarnegara untuk RCP 2.6, RCP 4.5 dan RCP 8.5 secara berurutan sebesar $0,26 \% ; 0,60 \%$; $0,52 \%$ dan pada Stasiun Kalisapi sebesar
$-1,54 \% ;-1,65 \% ;-2,20 \%$ dibandingkan dengan data historis tahun 2015-2019.

\subsection{Hasil Prediksi Tingkat Bahaya Erosi pada tahun 2020-2054}

Perhitungan USLE dilakukan dengan menggunakan overlay ArcGIS dan didapat prediksi tingkat bahaya erosi pada RCP 2.6, RCP 4.5 dan RCCP 8.5 dalam periode 20202054 seperti yang ditampilkan pada Gambar 2 . Dapat dilihat bahwa perubahan kategori kelas tingkat bahaya erosi untuk Kelas Erosi Sangat Ringan (a) dan Ringan (b) tidak terjadi perubahan yang signifikan hingga tahun 2049, sedangkan tahun 2050 baru terjadi perubahan pada kedua kategori kelas ini.

Pada kategori Kelas Erosi Sedang, penurunan terjadi pada tahun 2020 untuk ketiga RCP dan kembali naik untuk tahun 2025. Perubahan paling signifikan terjadi pada tahun 2050 dimana terjadi penurunan luas daerah yang signifikan. Untuk kategori Kelas Erosi Berat, perubahan terjadi cukup signifikan pada ketiga 


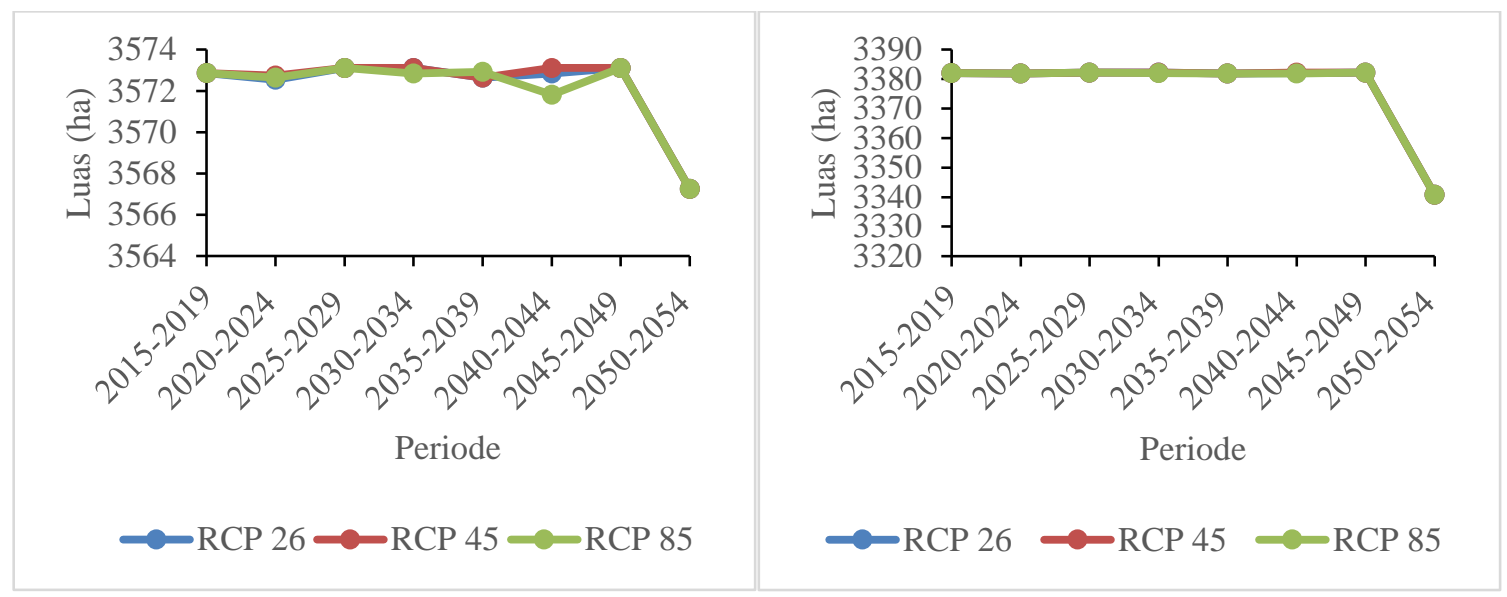

(a)

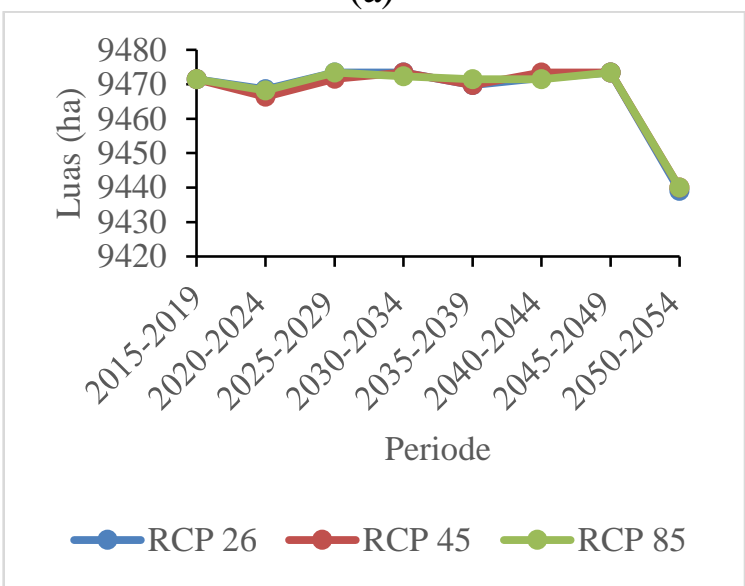

(c)

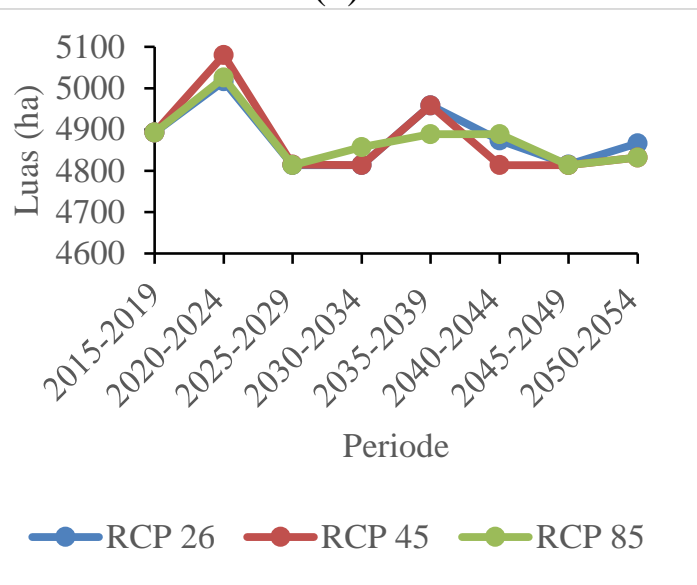

(d)

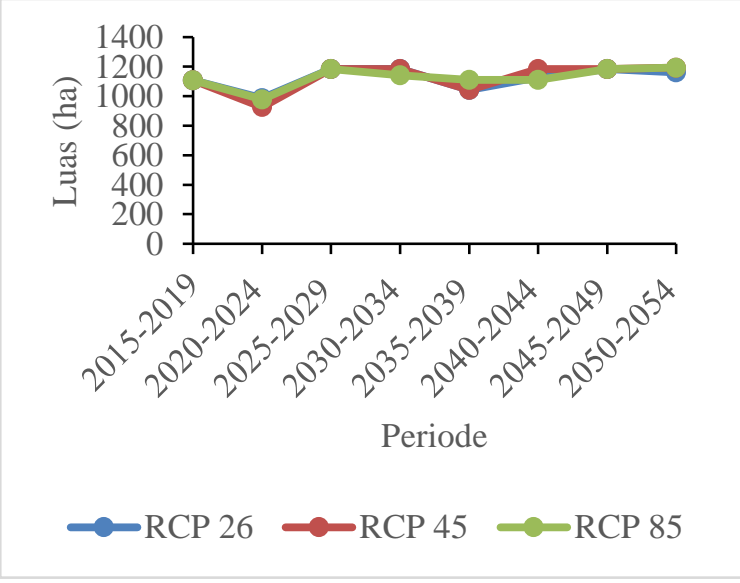

(e)

Gambar 2. Hasil Prediksi Tingkat Bahaya Erosi pada RCP 2.6, 4.5 dan 8.5 tahun 2020-2054 untuk Kelas Erosi Sangat Ringan (a), Kelas Erosi Ringan (b), Kelas Erosi Sedang (c), Kelas Erosi Berat (d) dan Kelas Erosi Sangat Berat (e)

RCP. Perubahan yang terjadi untuk Kelas Erosi Berat cenderung mengalami penurunan nilai luas daerah yang terdampak erosi kelas berat. Untuk kategori Kelas Erosi sangat berat, nilainya cenderung naik untuk ketiga RCP.
Menurut Ruminta et al. (2018), selama beberapa abad terakhir perubahan iklim membuat pergeseran pola curah hujan, kenaikan suhu global dan peningkatan intensitas cuaca ekstrim. Hal ini dapat 
meningkatkan potensi bencana banjir, kekeringan dan erosi tanah. Pernyataan ini sesuai dengan pendapat Yang et al. (2003), yang menyebutkan bahwa rata-rata erosi tanah diproyeksikan naik hingga $9 \%$ pada tahun 2090 dikarenakan perubahan iklim. Gambar 3 memperlihatkan Peta Tingkat Bahaya Erosi tahun 2015-2019, DAS Merawu, Kabupaten Banjarnegara selama 5 tahun terakhir.

Prediksi perubahan tingkat kerentanan erosi tahun 2020-2050 di Sub DAS Merawu, Kabupaten Banjarnegara pada RCP 2.6 untuk kelas erosi sangat ringan turun $-0,02 \%$, ringan turun $-0,17 \%$, sedang turun $-0,05 \%$, berat turun $-0,26 \%$, sangat berat naik $1,46 \%$; pada RCP 4.5 untuk kelas erosi sangat ringan turun $-0,02 \%$, ringan turun $-0,17 \%$, sedang turun $-0,05 \%$, berat turun $-0,35 \%$, sangat berat naik
1,88\%; dan pada RCP 8.5 untuk kelas erosi sangat ringan turun $-0,03 \%$, ringan turun $-0,17 \%$, sedang turun $-0,04 \%$, berat turun $-0,37 \%$, sangat berat naik $1,95 \%$.

\subsection{Hasil Prediksi Rata-rata Erosi dan Sedimentasi pada tahun 2020-2054}

Selain melakukan analisa luas daerah dengan kategori erosi tertentu, pada penelitian ini juga dilakukan analisa erosi rerata selama periode 5 tahunan dari 2020-2050an. Setelah dilakukan analisa rerata erosi, selanjutnya dilakukan perhitungan sedimentasi untuk membandingkan hasil erosi yang diperoleh dengan data sedimentasi dari Data Volume Sedimen Waduk Panglima Besar Soedirman PT. Uni Indonesia Power UBP Waduk Mrica 1989-2017 yang terdapat dalam kajian Marhendi (2018).

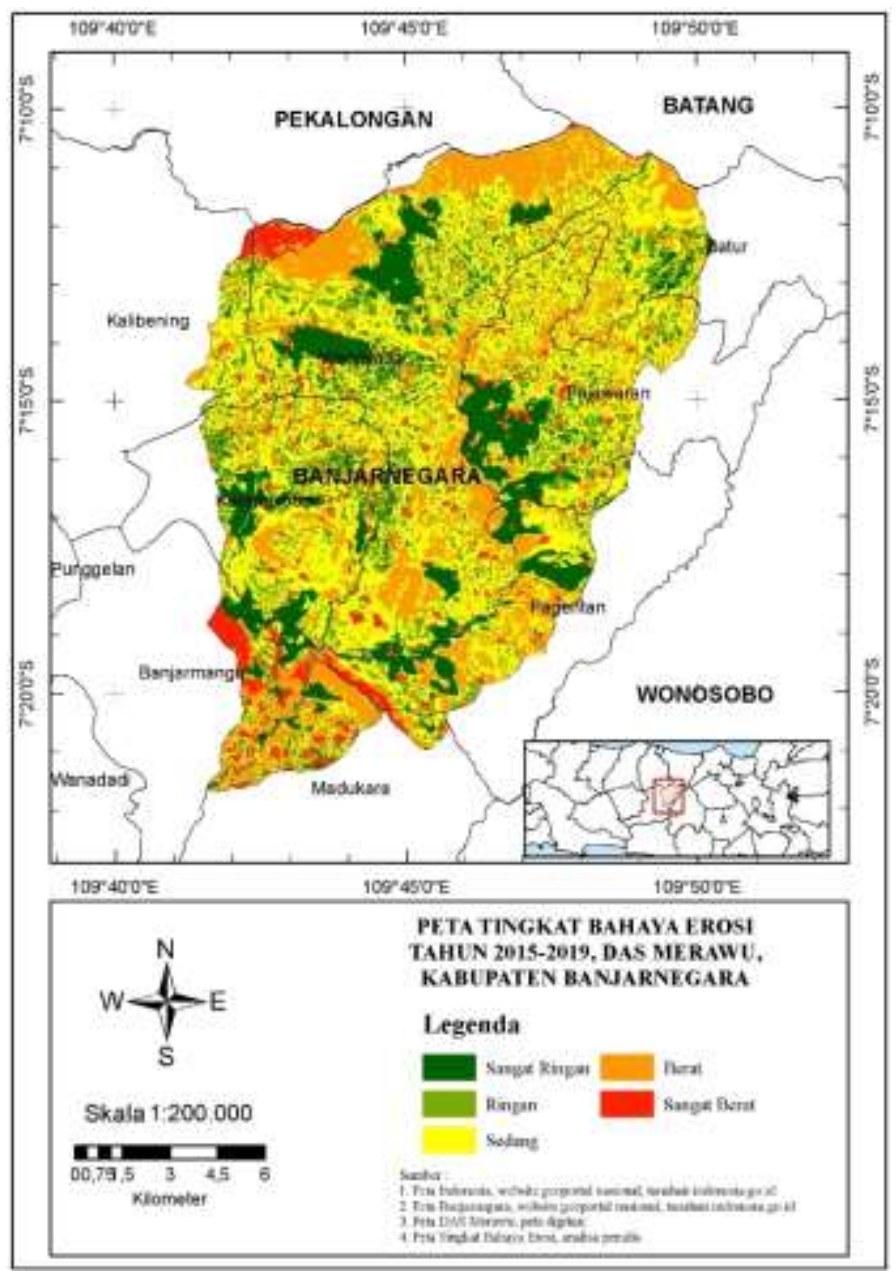

Gambar 3. Peta Tingkat Bahaya Erosi tahun 2015-2019, DAS Merawu, Kabupaten Banjarnegara 


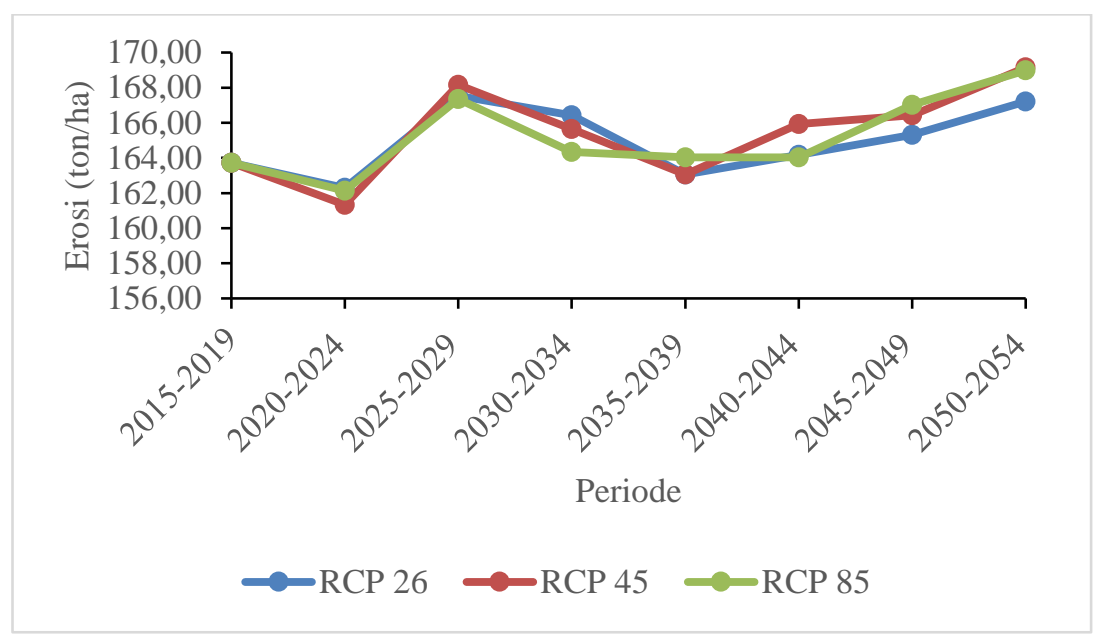

Gambar 4. Grafik rata-rata erosi pada 2015-2054 dengan RCP 2.6, RCP 4.5 dan RCP 8.5, DAS Merawu, Kabupaten Banjarnegara

Untuk nilai prediksi rata-rata erosi tahun 2020-2050 pada RCP 2.6 naik 0,86\%, RCP 4.5 naik $1,19 \%$ dan RCP 8.5 naik $1,03 \%$ dibandingkan dengan data historis tahun 2015-2019. Nilai rerata tersebut dihitung 5 tahunan dari 2015 hingga 2050. Hasil rerata erosi dapat dilihat pada Gambar 4.

Secara umum kenaikan rerat erosi terjadi pada semua RCP. Namun pada RCP 2.6 nilainya cenderung tidak setinggi RCP 8.5. Hal ini terjadi karena pada RCP 8.5 nilai erosivitasnya cenderung naik disebabkan karena perubahan iklim yang terlalu ekstrim. Untuk nilai rerata erosi tertinggi terjadi pada RCP 4.5 dengan nilai rerata erosi 169,15 ton.ha ${ }^{-1}$.tahun ${ }^{-1}$. Pada RCP 4.5 perubahan iklim terjadi tidak seekstrim RCP 8.5 namun tetap terjadi perubahan erosivitas hujan yang signifikan. Sedangkan untuk nilai rerata erosi tahunan terendah terjadi pada RCP 4.5 juga, dengan nilai erosi 161,33 ton.ha-1.tahun ${ }^{-1}$. Untuk validasi data erosi dilakukan perhitungan sedimentasi yang terlihat pada Tabel 5 .

Menurut Marhendi dan Ningsih (2018), sedimentasi pada Waduk Mrica terjadi karena erosi tanah yang terbawa atau tergerus oleh sungai yang mengarah pada hulu Waduk Mrica. Sehingga nilai sedimentasi dapat dijadikan sebagai validasi terhadap hasil erosi tanah yang terjadi. Menurut Mekarsari dan Utomo (2019), sedimen merupakan hasil dari erosi dimana hasil sedimen yang dimaksud merupakan jumlah total sedimen yang mencapai sungai atau outlet DAS per tahunnya dan jumlahnya selalu lebih kecil daripada total erosi yang terjadi di DAS tersebut.

Nilai sedimentasi dihitung menggunakan nilai bulk density dari Sulistyo (2011), dimana menurut hasil analisa jurnal tersebut, niai rerata bulk density DAS Merawu sebesar 1,60 $\mathrm{gr} / \mathrm{cm}^{3}$ dimana nilai tertinggi adalah 2,16 $\mathrm{gr} / \mathrm{cm}^{3}$ dan nilai terendah adalah $1,03 \mathrm{gr} / \mathrm{cm}^{3}$. Nilai yang terdapat pada Tabel 5. tersebut dalah nilai rerata dari sedimentasi selama 5 tahun sehingga fluktuasi sedimen tahunan tidak terlihat signifikansinya.

Untuk nilai sedimentasi rata-rata, nilai tertinggi terjadi pada RCP 4.5 tahun 20502054 yakni sebesar 2.396.221,19 m3. Sedangkan nilai terendah terjadi pada tahun 2020-2024 pada RCP 4.5 dengan nilai 2.285.441,11 m3. Pada RCP 2.6, nilainya cenderung lebih kecil dibanding dengan nilai RCP 4.5 dan RCP 8.5. Hal ini terjadi karena pada RCP 2.6 nilai puncak pancaran radiasi pada pertengahan abad sebesar $3 \mathrm{~W} / \mathrm{m}^{2}$ sehingga perubahan curah hujan karena perubahan iklim tidak se-ekstrim RCP 4.5 dan RCP 8.5. Dan untuk RCP 8.5, nilainya cenderung lebih tinggi dibanding yang lain karena pada RCP 8.5 terjadi skenario perubahan iklim yang cukup ekstrim sehingga nilainya cenderung lebih tinggi. 
Tabel 5. Tabel Hasil Prediksi Rerata Erosi dan Sedimentasi pada RCP 2.6, 4.5 dan 8.5 pada 2020-2054

\begin{tabular}{cccc}
\hline \multirow{2}{*}{ Tahun } & Data & $\begin{array}{c}\text { Rerata Erosi } \\
\text { (ton/ha) }\end{array}$ & $\begin{array}{c}\text { Sedimentasi } \\
\left(\mathrm{m}^{3}\right)\end{array}$ \\
\hline $2015-2019$ & Historikal & 163,73 & $2.319 .440,11$ \\
\hline \multirow{2}{*}{$2020-2024$} & RCP 2.6 & 162,29 & $2.299 .040,71$ \\
& RCP 4.5 & 161,33 & $2.285 .441,11$ \\
& RCP 8.5 & 162,13 & $2.296 .774,11$ \\
\hline \multirow{2}{*}{$2025-2029$} & RCP 2.6 & 167,53 & $2.373 .271,86$ \\
& RCP 4.5 & 168,16 & $2.382 .196,60$ \\
$2030-2034$ & RCP 8.5 & 167,36 & $2.370 .863,60$ \\
\hline \multirow{2}{*}{$2035-2039$} & RCP 2.6 & 166,43 & $2.357 .688,99$ \\
& RCP 4.5 & 165,64 & $2.346 .497,65$ \\
& RCP 8.5 & 164,35 & $2.328 .223,19$ \\
\hline \multirow{2}{*}{$2040-2044$} & RCP 2.6 & 163,06 & $2.309 .948,73$ \\
& RCP 4.5 & 163,06 & $2.309 .948,73$ \\
& RCP 8.5 & 164,02 & $2.323 .548,33$ \\
\hline \multirow{2}{*}{$2045-2049$} & RCP 2.6 & 164,18 & $2.325 .814,93$ \\
& RCP 4.5 & 165,93 & $2.350 .605,86$ \\
& RCP 8.5 & 164,02 & $2.323 .548,33$ \\
\hline \multirow{2}{*}{$2050-2054$} & RCP 2.6 & 165,31 & $2.341 .822,79$ \\
& RCP 4.5 & 166,43 & $2.357 .688,99$ \\
& RCP 8.5 & 167,03 & $2.366 .188,74$ \\
\hline & RCP 2.6 & 167,20 & $2.368 .597,00$ \\
& RCP 4.5 & 169,15 & $2.396 .221,19$ \\
& RCP 8.5 & 168,98 & $2.393 .812,93$ \\
\hline
\end{tabular}

Menurut Julismin (2013), keadaan dapat menjadi lebih buruk karena perubahan iklim jika masyarakat dan ekosistem memiliki kemampuan adaptasi yang rendah karena perubahan iklim memiliki kecenderungan menyebabkan daerah kering akan semakin kering dan daerah basah akan semakin basah. Hal ini tentu menjadi perhatian bagi daerahdaerah yang rawan bencana erosi dan longsor, karena daerah tersebut memiliki potensi menghadapi bencana alam yang lebih berat dibanding tahun-tahun sebelumnya.

\section{KESIMPULAN}

Berdasarkan hasil analisa yang dilakukan, dapat ditarik kesimpulan sebagai berikut:

1. Prediksi perubahan curah hujan tahun 2020-2050 di Sub DAS Merawu yang disebabkan karena faktor $1.000 \mathrm{hPa}$ Zonal velocity dan Screen $(2 \mathrm{~m}$ ) air temperature pada Stasiun Banjarnegara dan Kalisapi untuk RCP 2.6, RCP 4.5 dan RCP 8.5 secara berurutan sebesar $0,26 \% ; 0,60 \% ; 0,52 \%$ dan $-1,54 \% ;-1,65 \% ;-2,20 \%$ dibandingkan dengan data historis tahun 2015-2019.

2. Prediksi perubahan tingkat kerentanan erosi tahun 2020-2050 di Sub DAS Merawu, Kabupaten Banjarnegara pada RCP 2.6 untuk kelas erosi sangat ringan turun $0,02 \%$, ringan turun $-0,17 \%$, sedang turun $0,05 \%$, berat turun $-0,26 \%$, sangat berat naik 1,46\%; pada RCP 4.5 untuk kelas erosi sangat ringan turun $-0,02 \%$, ringan turun $0,17 \%$, sedang turun $-0,05 \%$, berat turun $0,35 \%$, sangat berat naik 1,88\%; dan pada RCP 8.5 untuk kelas erosi sangat ringan turun $-0,03 \%$, ringan turun $-0,17 \%$, sedang turun $-0,04 \%$, berat turun $-0,37 \%$, sangat berat naik $1,95 \%$; sedangkan untuk nilai prediksi rata-rata erosi tahun 2020-2050 pada RCP 2.6 naik $0,86 \%$, RCP 4.5 naik $1,19 \%$ dan RCP 8.5 naik 1,03\% dibandingkan dengan data historis tahun 2015-2019. 


\section{DAFTAR PUSTAKA}

Aiqiu, L.F., Mahendera, I.G.A., Mulsandi, A. 2017. Analisis Kondisi Atmosfer pada Kejadian Hujan Lebat Daerah Poso dan Sekitarnya (Studi Kasus: Kabupaten Poso Tanggal 17 Juli 2017). Seminar Nasional Penginderaan Jauh ke-4 Tahun 2017: 383-393.

Asuero, A.G., Sayago, A. dan Gonzalez, A.G. 2006. The Correlation Coefficient: An Overview. Critical Reviews in Analytical Chemistry, 36: 41-59.

Bappenas. 2018. Kaji Ulang RAN API: Kajian Basis Ilmiah Proyeksi Iklim Atmosferik. Bappenas, Jakarta, 51 hal.

Chai, T dan Draxler, R.R. 2014. Root mean square error (RMSE) or mean absolute error (MAE)? Arguments against avoiding RMSE in the literature. Geosci. Model Dev., 7: 1247-1250.

Duhan, D. dan Pandey, A. 2015. Statistical downscaling of temperature using three Techniques in the Tons River basin in Central India. Theoretical and Applied Climatology, 121: 605-622.

Julismin. 2013. Dampak dan Perubahan Iklim di Indonesia. Jurnal Geografi, 5 (1): 39-46.

Marhendi, T. 2011. Pengaruh Anomali Karakteristik Hujan Terhadap Erosi Lahan (Studi Kasus Das Merawu, Jawa Tengah). Techno, 12: 45-52.

Marhendi, T. dan Ningsih, D.L.S. 2018. Prediksi Peningkatan Sedimentasi Dengan Metode Angkutan Sedimen (Studi Kasus Sedimentasi Di Waduk Mrica). Techno, 19: 87-94.

Mawardi, I., 2010. Kerusakan Daerah Aliran Sungai dan Penurunan Daya Dukung Sumberdaya Air Di Pulau Jawa Serta Upaya Penanganannya. Hidrosfir Indonesia, 5: 1-11.

Mekarsari, R. dan Utomo, P. 2019. Analisis Tingkat Bahaya Erosi pada Waduk Wadaslintang dengan Aplikasi Arcgis. Jurnal Geografi Gea, 19(2): 93-104.

Moriasi, D.N., Arnold, J.G., van Liew, M.W., Binger, R.L., Harmel, R.D. dan Veith, T.L. 2007. Model Evaluation Guidelines For
Systematic Quantification Of Accuracy In Watershed Simulations. Transactions of American Society of Agricultural and Biological Engineers, 50 (3): 885-900.

Nearing, M.A., 2001. Potential changes in rainfall erosivity in the U.S. with climate change during the 21st century. J. Soil Water Conserv., 56: 229-232.

Nugroho, B.D.A. 2020. Fenomena Iklim Global, Perubahan Iklim dan Dampaknya di Indonesia. Gadjah Mada University Press, Yogyakarta.

Polade, S.D., Gershunov, A., Cayan, D.R., Dettinger, M.D., dan Pierce, D.W., 2017. Precipitation in a warming world: assessing projected hydro-climate changes in California and other Mediterranean climate regions. Sci. Rep. 7: 10783.

Poli, A.A dan Cirillo, M.C. 1993. On The Use Of The Normalized Mean Square Error In Evaluating Dispersion Model Performance. Atmospheric Environment 27A(15): 24272434.

Ruminta, Handoko dan Nurmala, T. 2018. Indikasi perubahan iklim dan dampaknya terhadap produksi padi di Indonesia (Studi kasus : Sumatera Selatan dan Malang Raya). Jurnal Agro, 5 (1) : 48-60.

Sulistyo, B. 2011. Pengaruh Erosivitas Hujan Yang Diperoleh Dari Rumu Yang Berbeda Terhadap Pemodelan Erosi Berbasis Raster (Studi Kasus di Das Merawu, Banjarnegara, Jawa Tengah). AGRITECH, 31 (3): 250-259.

Wischmeier, W.H dan Smith, D. D. 1978. Predicting Rainfall Erosion Losses A Guide to Conservation Planning. Washington DC: Goovernment Printing Office.

World Meteorological Organization. 1981. Measurement of River Sediments. Secretariat of the World Meteorological Organization, Switzerland : Operational Hydrology Report No. 16.

Yang, D., Kanae, S., Oki, T., Koike, T., dan Musiake, K., 2003. Global potential soil erosion with reference to land use and climate changes. Hydrol. Process. 17: 2913-2928. 